\title{
The Rise of E-Learning in COVID-19 Pandemic in Private University: Challenges and Opportunities
}

\author{
Daniel Hermawan \\ Parahyangan Catholic University, Bandung, Indonesia
}

\begin{tabular}{|c|c|}
\hline (A) Check for updates open access (c) (i) (2) & DOI : https://doi.org/10.46245/ijorer.v2i1.77 \\
\hline Sections Info & ABSTRACT \\
\hline Article history: & The COVID-19 pandemic which is occurring all over the world indeed \\
\hline Submitted: December 24, 2020 & has many negative impacts in various aspects. On the other hand, the \\
\hline Final Revised: January 13, 2021 & COVID-19 pandemic aroused the use of e-learning which has been seen \\
\hline Accepted: January 14, 2021 & as a complementary medium in the education process in Indonesia. This \\
\hline Published Online: January 31, 2021 & research aims to explore the challenges and opportunities felt by students \\
\hline Keywords: & in private university by implementing e-learning as an innovative \\
\hline COVID-19 & learning method in the future. Through the mixed method approach, it \\
\hline Digital & can be concluded that e-learning can be accepted as an educational \\
\hline E-learning & solution in dealing with the COVID-19 pandemic, but it still requires \\
\hline Knowledge & improvements in terms of comfort, infrastructure, and absorption of \\
\hline Perception & knowledge so that e-learning does not merely move classrooms into \\
\hline 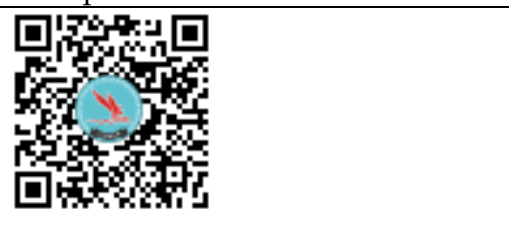 & $\begin{array}{l}\text { digital classrooms, but also provides a holistic experience that makes it } \\
\text { easier for students to learn and gain knowledge. Research provide } \\
\text { student perspectives in undergoing e-learning which is expected to be a } \\
\text { recommendation for universities to provide a good e-learning experience. } \\
\text { In addition, there is an evaluative step for the lecturer in optimally } \\
\text { optimizing e-learning design. }\end{array}$ \\
\hline
\end{tabular}

\section{INTRODUCTION}

The COVID-19 pandemic has changed various aspects of people's lives, ranging from the economic, social, political, to education sectors. The virus, thought to originate from the Huanan Seafood Market in Wuhan, Hubei, China, has infected more than 1.6 million people and caused the death of more than 95,722 people worldwide. Given the health impacts and threats posed by the COVID-19 pandemic, governments in various countries have begun to impose regional traffic restrictions, better known as "lockdowns" (Rizal, 2020; worldometers, 2020). In Indonesia, the implementation of large-scale social restrictions was carried out to limit the spread of the COVID-19 virus that occurred in Jakarta (Wijaya, 2020).

Since the issuance of the Letter from the Secretary General of the Ministry of Education and Culture No. 36603/A.A5/OT/2020 concerning Prevention of Corona Virus Disease (COVID-19) in the Ministry of Education and Culture, universities in Indonesia have been encouraged to conduct distance learning otherwise known as online education or e-learning (Dikti, 2020). It is hoped that through online interaction, the social distancing principle promoted by the Indonesian government can break the chain of the spread of the COVID-19 virus originating from droplets or saliva splashes (Putra, 2020).

Globally, the COVID-19 virus has given negative excesses to economic growth in various fields, such as tourism, manufacturing, transportation, and creative industries (Fajar, 2020). But on the other hand, the phenomenon of COVID-19 has provided a new 
ecosystem in the field of education, namely the increase in users of e-learning applications and online meetings in a relatively short time (Irawan, 2020). Online

meeting applications, such as Google Hangouts Meet, Zoom, Skype, Microsoft Team, Webex Meet, etc. have experienced dramatically increased user growth. There are 6.7 million downloads recorded on the online meeting application until the first week of March 2020 (Isna, 2020).

E-learning is the use of digital media to accommodate the learning process in class (Arkorful \& Abaidoo, 2014). Before the COVID-19 pandemic, e-learning was a complementary medium that only served as a supplement to the learning process in the classroom. However, since the increase in positive cases of COVID-19, e-learning has become a necessity to continue providing the educational process, on the other hand, protecting university stakeholders from the threat of the COVID-19 pandemic (Rahardyan, 2020). E-learning can be found from various existing learning media, starting from language apps, video conferencing tools, virtual tutoring, online learning software, moodle, and many more (Li \& Lalani, 2020).

The application of e-learning in the learning process during the COVID-19 pandemic is not without challenges (Siagian, 2020). The limited digital infrastructure in tertiary institutions, especially those outside Java, the relatively unstable condition of the internet connection, and the availability of media to carry out e-learning vary widely between students with various economic levels (APJII, 2020). In addition, the success of e-learning also greatly depends on the economic and psychological side of students during the COVID-19 pandemic (Kasih, 2020). Financial, social, and family cultural conditions that require students to study in different conditions, no longer in the confines of the classroom, are things that need to be considered in e-learning (Azzahra, 2020).

Seeing the phenomena that occur, e-learning has now become a rational choice in addressing the educational process in the COVID-19 pandemic (Gupta \& Khairina, 2020). Educational innovations that minimize physical interaction face-to-face are expected to remain capable of being an optimal means of transfer of knowledge between teachers and students in the college environment. Therefore, this research will highlight the rise of e-learning in the COVID-19 pandemic in terms of challenges and opportunities.

\section{Theoretical Frameworks}

Online education or e-learning is actually not a new concept in the world of education. The practice of e-learning can be seen in Computer Based Training (CBT) in 1990 (Nwlink, 2010). Simply put, computers began to be used as a medium for sending and working on material provided visually with instructions. Furthermore, e-learning continues to develop along with the development of technology in the field of ICT until various online applications emerge that can be accessed via devices, be it smartphones, laptops, tablets, or PC computers (Ryan, 2020).

E-learning can be defined as a learning process that is mediated by the use of online technology (Pacansky-Brock, 2012). There are a number of benefits derived from the online learning process, such as not requiring costs in the process of traveling to and from home/university; can adjust the schedule flexibly; learn at your own pace (Aladwan \& Smedly, 2012). But there are also some weaknesses in the e-learning process, 
such as the lack of interaction or emotional closeness built with digital platforms; high costs for producing quality educational content online; difficult to ascertain the level of understanding of students; there are many disturbances, both the availability of infrastructure, internet quota, and the quality of the device (Nelson \& Erlandson, 2012).

The use of e-learning in the learning process can be of 3 types, namely adjunct, blended, and wholly online (Algahtani, 2011). In wholly online, it can be divided into individualized learning and collaborative learning. Individualized learning means that students independently carry out the learning process by looking for information in digital media. Meanwhile, collaborative learning is divided into synchronous and asynchronous. Synchronous means that communication between lecturers and students is established in real time with the help of digital media, meanwhile asynchronous means that there are different times between lecturers and students in interacting in the learning process, it can be in the form of previously prepared learning video recordings or uploading material in internet.

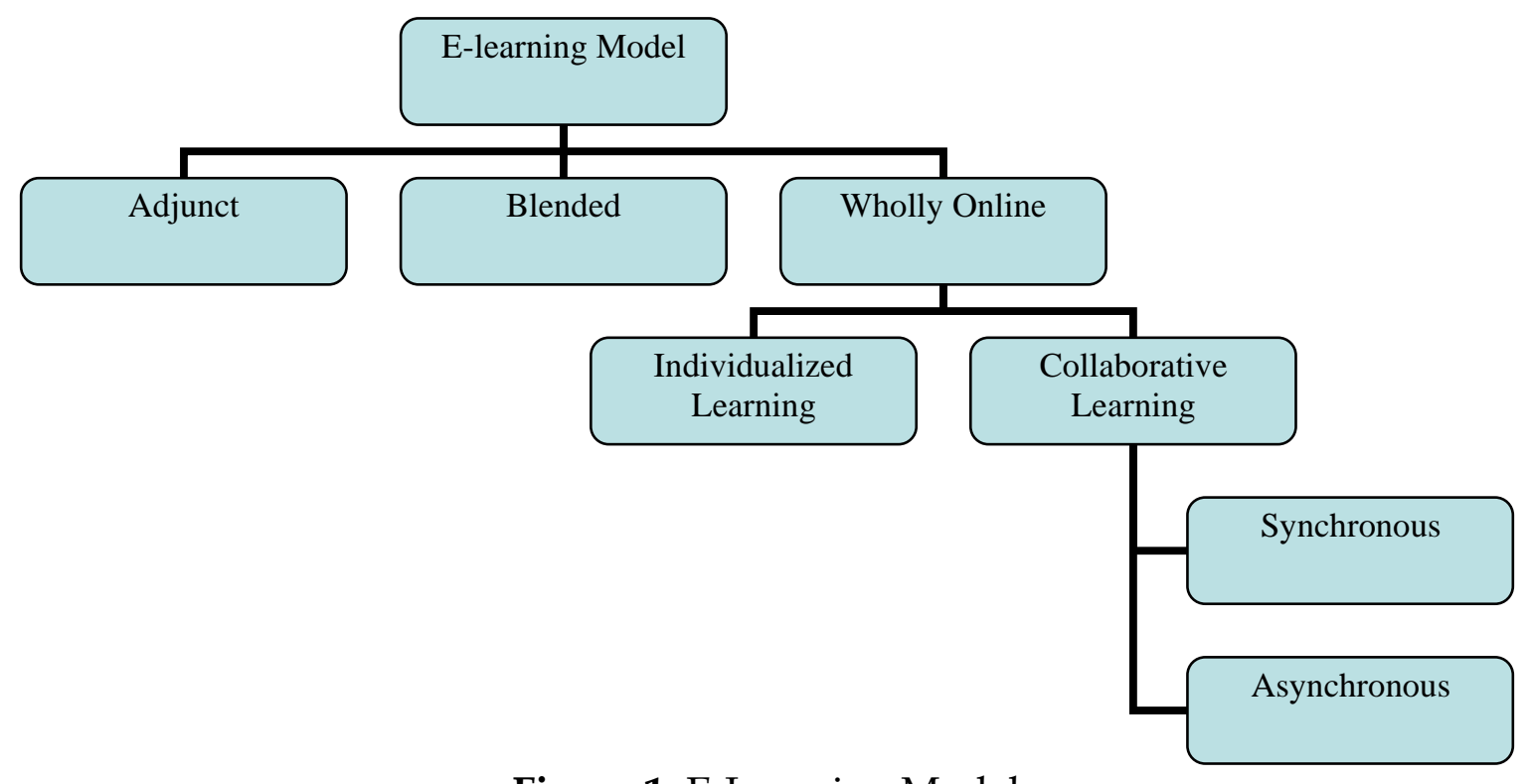

Figure 1. E-Learning Model

Source: (Algahtani, 2011)

There are 4 dimensions that can support the e-learning process in learning, such as student - student interaction, student - teacher interaction, student - resource interaction, and student - computer interaction through various online meeting platforms and applications available today, such as Google Classroom, Zoom, Google Hangouts Meet, moodle independently managed by the university, and so on (FAO, 2011).

In the process of implementing e-learning, there 5 stages to achieve participation and success of e-learning. Participants need to master technical and online communication skills, such as access and motivation - welcoming and encouraging; online socialization - familiarization, socialization; information exchange - task facilitation and use of learning materials; knowledge construction - facilitating process; development supporting and responding (Sun \& Chen, 2016). These five stages need to be considered to ensure the learning objectives that have been formulated in the Semester Learning 
Plan (RPS) can be met, even though they are delivered on different platforms (Abedini, 2020).

\section{RESEARCH METHOD}

This research aims to explore the perceptions and perspectives of private university students related to the e-learning process that was applied during the COVID-19 pandemic. The research used mixed method that aims to explore students' views on the use of e-learning platforms, both institutionally facilitated through Moodle, or freely facilitated by online meeting provider applications, such as Google Hangouts Meet, Zoom, etc., as well as measuring students' perceptions of online education on a Likert scale through online questionnaires (Sugiyono, 2016).

The data were analyzed using mixed methods, in which this research used equal combination between quantitative and qualitative method (concurrent triangulation strategy). This method is used to obtain a more comprehensive understanding and data from students' perceptions about the implementation of e-learning in private universities, especially in 4 indicators, namely perception, attitudes, infrastructure, and absorption of knowledge.

The sample of this research is students who are studying at private universities in Bandung. The data collection technique was done by using purposive sampling. A total of 186 students were successfully obtained as research samples after going through a series of criteria determined in the study, namely having conformity with the characteristics and indicators examined in this study, namely e-learning. Measurement tools in this research have been tested for validity and reliability, so that it can measure the indicators studied in this research.

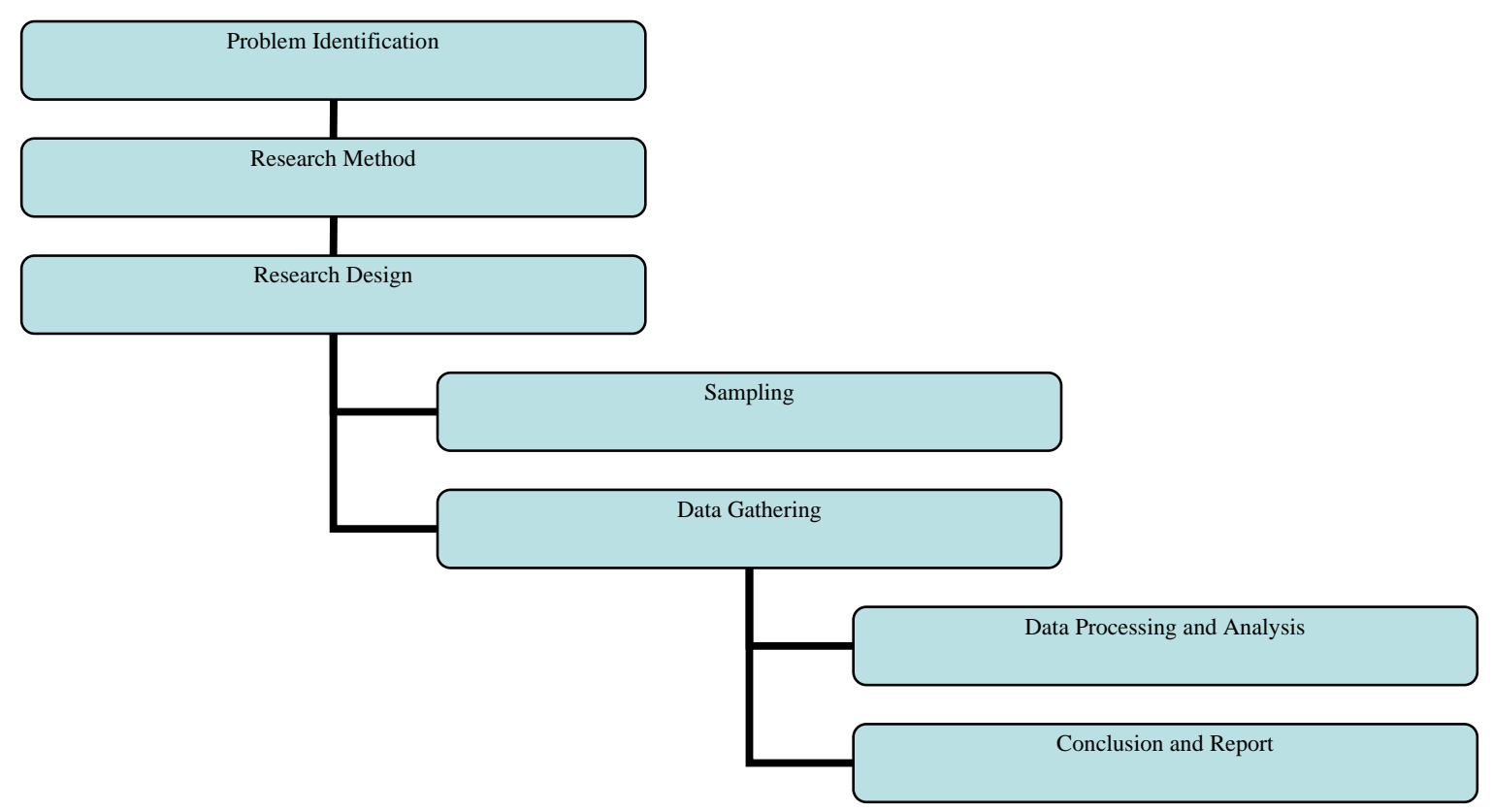

Figure 2. Research Procedure

\section{RESULTS AND DISCUSSION}

Based on the results of a research of 186 private university students, aged 17-24 years with the majority of male demographic characteristics (54.84\%), living together with parents (55.91\%), domiciled in Bandung (55.38\%), using an internet connection with 
broadband internet from internet service providers $(67.74 \%)$, and using a laptop/netbook when accessing online lectures (48.92\%) are seen in Table 1. This condition most likely similar with School Education Gateway (2020) that students mostly conduct e-learning from home with varying family conditions.

Table 1. Demographics of respondents.

\begin{tabular}{|c|c|c|}
\hline Numb. & Description & Information \\
\hline 1 & Sex & $\begin{array}{l}\text { Male } 102(54.84 \%) \\
\text { Female } 84(45.16 \%)\end{array}$ \\
\hline 2 & Housing in Bandung & $\begin{array}{l}\text { House with parents } 104(55.91 \%) \\
\text { Relatives's house } 9(4.84 \%) \\
\text { Apartments } 7(3.76 \%) ; \\
\text { Boarding's Room } 64(34.41 \%) \\
\text { Rent a House } 2(1.08 \%)\end{array}$ \\
\hline 3 & Current Domicile & $\begin{array}{l}\text { Bandung and surrounding areas } 121(65.05 \%) ; \\
\text { Jabodetabek } 32(17.20 \%) ; \\
\text { West Java } 16(8.60 \%) ; \\
\text { Central Java } 4(2.15 \%) ; \\
\text { Bali } 2(1.08 \%) ; \\
\text { Sumatra } 8(4.30 \%) ; \\
\text { Kalimantan } 2(1.08 \%) ; \\
\text { Sulawesi } 1(0.54 \%)\end{array}$ \\
\hline 4 & $\begin{array}{l}\text { The device to access } \\
\text { online lectures }\end{array}$ & $\begin{array}{l}\text { Android Smartphones } 48(25.81 \%) \\
\text { iOS Smartphones } 42(22.58 \%) \\
\text { Laptops/netbooks } 91(48.92 \%) \\
\text { PC computer } 5(2.69 \%)\end{array}$ \\
\hline 5 & $\begin{array}{l}\text { The type of internet } \\
\text { connection }\end{array}$ & $\begin{array}{l}\text { Internet quota/package } 47(25.27 \%) \text {; } \\
\text { Wi-Fi/broadband internet from internet service providers } \\
\text { (IndiHome, First Media, Biznet, etc.) } 126(67.74 \%) ; \\
\text { Wi-Fi's from boarding's room/apartment } 13(6.99 \%)\end{array}$ \\
\hline
\end{tabular}

Research measured several indicators related to student perceptions in the use of elearning which are applied $100 \%$ by universities through sharing platforms that are available, both for free, such as Zoom, Google Hangouts Meet, and various other platforms, as well as institutionally, in form of university moodle. The medium of elearning also has been studied in Reyes-Chua (2020) that adapted during COVID-19 pandemic mostly free platforms. The indicators studied are related to perceptions, attitudes, infrastructure, and ease of use/absorption of information/knowledge. The link between these indicators can be seen in Figure 1. 


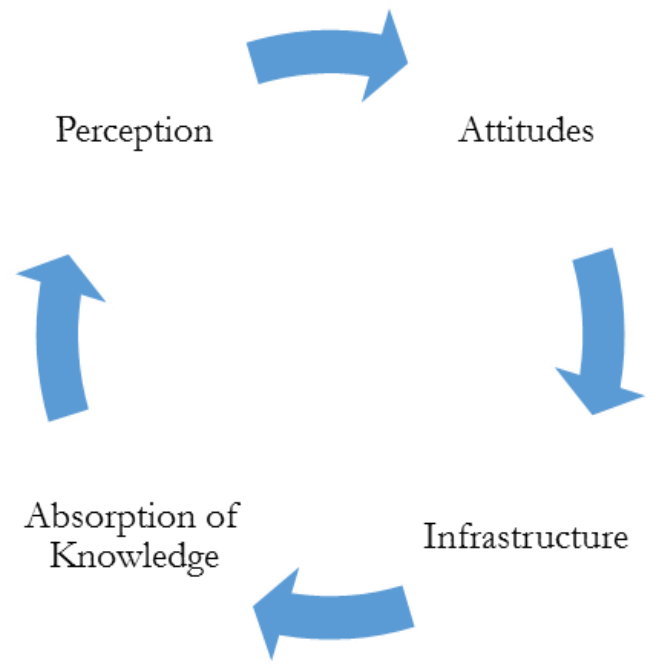

Figure 3. Student adoption cycle in e-learning.

Table 2. E-learning's indicators and perception.

\begin{tabular}{cclc}
\hline Numb. & Indicator & Items & $\%$ \\
\hline $\mathbf{1}$ & Perception & $\begin{array}{l}\text { E-learning is the right solution to } \\
\text { prevent the spread of Covid-19 }\end{array}$ & 89.2 \\
\hline $\mathbf{2}$ & Attitudes & I am comfortable researching online & 66.6 \\
\hline $\mathbf{3}$ & Infrastructure & $\begin{array}{l}\text { E-learning technology in Indonesia is } \\
\text { sufficient }\end{array}$ & 69.8 \\
\hline $\mathbf{4}$ & $\begin{array}{c}\text { Absorption of } \\
\text { Knowledge }\end{array}$ & $\begin{array}{l}\text { E-learning makes it easy for me to } \\
\text { get knowledge from lecturers }\end{array}$ & 64.6 \\
\hline
\end{tabular}

Through Table 2, it can be concluded that in terms of perception, students accept elearning as a solution offered during the COVID-19 pandemic, enriched with students' opinion that e-learning is an opportunity for them to get to know new tools that have never been used in the learning process all this time. In addition, they can learn more independently, flexibly, and arrange schedules responsibly, remembering that learning is carried out individually through their respective homes. This result strengthen with Luaran (2014) that underline flexibility to learn and choose either instructor-led or selfstudy courses, also learn without space and time dividers.

In terms of attitude, students feel comfortable using e-learning because they can use various digital platforms or attend classes anywhere without having to be physically bound in a class. In addition, they can record e-learning, so they can repeat the material taught independently. Convenience is also felt in terms of practicality and also savings because it minimizes transportation costs that must be spent on campus. However, this attitudes point is not high enough considering the limitations of e-learning which are judged to be located at a low level of interaction, as well as a greater quantity of assignments compared to face-to-face lectures. This issue also enriched in Mamattah (2016), that e-learning is not an appropriate medium to study courses that have practical components, such as laboratory and class that deals with computation.

In terms of infrastructure, students feel that the infrastructure to access the internet in Indonesia based on each residence is good enough. Also supported by data that $67.74 \%$ of students subscribe to the internet from internet service providers. This score is not significant considering that there are still many constraints on infrastructure that are 
still being felt, such as the difficulty of getting signals in certain regions, networks that like to experience slowdowns, sometimes there are power outages at certain times, up to uncertain internet speeds. In addition, the noise factor in the home and fatigue in staring at the device screens are constraints that are felt to hinder students in e-learning. This result also supported by Daniels (2019), which highlighting e-learning framework that could accomodate offline version and support to overcome internet issue.

E-learning is considered to make it easier for students to get knowledge from lecturers, but it has not been significantly seen from the reluctance when asking in an online session, some quantitative material will be difficult to understand digitally, learning tends to be one-way between lecturers and students, some lecturers who stutter technology will find it difficult to make e-learning lectures interesting. In addition, the absorption of knowledge also tends to be less than optimal because the audio intonation or lecturer voice that is too slow/fast/low will affect the process of transfer of information obtained by students. Previous study that carried out by Bączek (2020) also underlines lack of interactions, technical problems, and less active students as the main disadvantages.

Through research also students revealed that $37.43 \%$ reminded the duration of elearning between $30-45$ minutes, followed by $29.41 \%$ for the duration of $15-30$ minutes, and $24.06 \%$ for the duration of $45-60$ minutes. This duration becomes rational considering that e-learning uses electronic devices and a large internet quota, and there is visual fatigue when staring at the smartphone or computer screen continuously, so that e-learning lectures cannot necessarily be done with the same duration as meetings face to face, but the content and duration must be adjusted accordingly. At the same time, Ngampornchai (2016) give recommendation that the e-learning platform may need to be mobile-friendly to accommodate students who may access online lessons using their smartphones.

\section{CONCLUSIONS}

The rise of e-learning as an alternative learning tool in the midst of the COVID-19 pandemic in private university has various challenges and opportunities. In terms of challenges, aspects of attitudes, infrastructure, and adsorption of knowledge from students still need to be improved considering that e-learning does not merely make all face-to-face learning online, but also packaging existing lectures becomes lighter and easier to understand with a level of interactivity that is low between lecturers and students. In addition, greater discipline and effort needs to be prepared by lecturers in minimizing monotonous and one-way lectures to be more participatory through a variety of independent modules and exercises conducted online pre or post lectures. In terms of opportunities, the rise of e-learning in the pandemic era of COVID-19 also emphasized the readiness of the Indonesian education world, especially private universities in preparing reliable infrastructure towards a digital campus. Moreover, one of the visions of the Indonesian government is "Making Indonesia 4.0", so that elearning education adopted today can be the right momentum to improve, and prepare for a mature digital infrastructure in the use and readiness of teaching staff and students. The COVID-19 pandemic is able to force all parties, including technology stuttering lecturers to take part in trying, and to adopt various digital platforms that enable the transfer of information and knowledge online. Certainly the challenges and 
opportunities of e-learning become natural in the transition phase of face-to-face education to distance education, but through a process of continuous innovation and learning, e-learning can later become a preferred educational method and bridge Indonesia's education that is spread from Sabang to Merauke optimally, as well as being a means for equitable distribution of the quality of national education which so far will be difficult to achieve only through face-to-face meetings.

This research has a number of limitations, one of which is only conducted to determine the implementation of e-learning in private universities, so that it cannot be generalized to public universities. In addition, the research only focuses on 4 main points, namely perception, attitudes, infrastructure, and absorption of knowledge, so it does not specifically measure other factors that may arise from the implementation of e-learning. In addition, the respondents in this study were students who were in the field of social sciences, so it might give different results if it was done for students who were in the field of science. This research can be developed in terms of lecturers, regarding how elearning changes the way lecturers prepare and deliver material to students. In addition, research can also be developed a mutually beneficial e-learning model between lecturers and students, which is able to provide a pleasant experience, on the other hand it is also able to meet the expected learning demands at the university. In addition, this research can be developed to find out the perceptions of students in public universities and remote areas in Indonesia to get another picture of the implementation of e-learning during the Covid-19 pandemic.

\section{REFERENCES}

Abedini, Y. (2020). Students' creativity in virtual vs. classroom courses on the basis of their personality traits: A prediction study. The Electronic Journal of e-Learning, 18(6), 525-536.

Al-adwan, A., \& Smedly, J. (2012). Implementing e-learning in the Jordanian higher education system: Factors affecting impact. International Journal of Education and Development using Information and Communication Technology (IJEDICT), 8(1), 121135.

Algahtani, A. F. (2011). Evaluating the effectiveness of the e-learning experience in some universities in saudi arabia from male students' perceptions. Durham: Durham University.

APJII. (2020, September 11). Infrastruktur masih jadi tantangan transformasi digital di daerah. $\quad$ Retrieved from APJII: https:/ / blog.apjii.or.id/index.php/2020/09/11/infrastruktur-masih-jaditantangan-transformasi-digital-di-daerah/

Arkorful, V., \& Abaidoo, N. (2014). The role of e-learning, the advantages and disadvantages of its adoption in Higher Education. International Journal of Education and Research, 2(12), 397-410.

Azzahra, N. F. (2020). Ringkasan kebijakan | Mengkaji hambatan pembelajaran jarak jauh di indonesia di masa Covid-19. Retrieved from Center for Indonesian Policy Studies: https://www.cips-indonesia.org/post/mengkaji-hambatan-pembelajaran-jarakjauhdi-indonesia-di-masa-covid-19 
Bączek, M., Zagańczyk-Bączek, M., Szpringer, M., Jaroszyński, A., \& WożakowskaKapłon, B. (2020). Students' perception of online learning during the COVID-19 pandemic: a survey study of Polish medical students. Kielce: Research Square.

Daniels, M. M., Sarte, E., \& Cruz, J. D. (2019). Students' perception on e-learning: a basis for the development of elearning framework in higher education institutions. The International Conference on Information Technology and Digital Applications (pp. 1-7). IOP Publishing.

Dikti. (2020, March 18). Himbauan kepada Pimpinan Perguruan Tinggi untuk dapat berbagi/sharing materi pembelajaran daring dengan membuka akses pembelajaran daring atau pembelajaran jarak jauh (PJJ). Retrieved from Dikti: http:/ / www.dikti.go.id/pengumuman/himbauan-kepada-pimpinan-perguruantinggi-untuk-dapat-berbagi-sharing-materi-pembelajaran-daring-denganmembuka-akses-pembelajaran-daring-atau-pembelajaran-jarak-jauh-pjj/

Fajar, T. (2020). Daftar sektor industri yang terdampak Covid-19, Apa saja? Retrieved from OkeFinance:

https:/ / economy.okezone.com/read/2020/04/08/320/2196153/daftar-sektorindustri-yang-terdampak-covid-19-apa-saja

FAO. (2011). E-learning methodologies: A guide for designing and developing e-learning courses. Rome: FAO.

Gupta, D., \& Khairina, N. N. (2020). COVID-19 dan ketidaksetaraan dalam proses belajar di Indonesia: Empat cara untuk menjembatani kesenjangan. Retrieved from World Bank: https:// blogs.worldbank.org/id/eastasiapacific/covid-19-dan-ketidaksetaraandalam-proses-belajar-di-indonesia-empat-cara-untuk

Honeycutt, L. (2011). Communication and design course. Retrieved from http:/ / dcr.rpi.edu/commdesign/class1.html.

Irawan, H. (2020). Inovasi pendidikan sebagai antisipasi penyebaran Covid-19. Retrieved from Ombudsman: https://ombudsman.go.id/artikel/r/artikel--inovasipendidikan-sebagai-antisipasi-penyebaran-covid-19

Isna, T. D. (2020). Work from home masif diterapkan, aplikasi kantor 'virtual' ini banjir unduhan hingga $5 x$ lipat. Retrieved from Warta Ekonomi: https:/ / www.wartaekonomi.co.id/read276786/work-from-home-masifditerapkan-aplikasi-kantor-virtual-ini-banjir-unduhan-hingga-5x-lipat

Kasih, A. P. (2020). Peta jalan pembelajaran jarak jauh: Peluang di tengah keterbatasan. Retrieved from Kompas.com: https:/ / www.kompas.com/edu/read/2020/09/03/061421871/peta-jalanpembelajaran-jarak-jauh-peluang-di-tengah-keterbatasan?page $=$ all

Li, C., \& Lalani, F. (2020). The COVID-19 pandemic has changed education forever. This is how. Retrieved from World Economic Forum: https://www.weforum.org/agenda/2020/04/coronavirus-education-globalcovid19-online-digital-learning/

Luaran, J. E., Samsuri, N. N., Nadzri, F. A., \& Rom, K. B. (2014). A study on the student's perspective on the effectiveness of using e-learning. Procedia - Social and Behavioral Sciences 123, 139-144.

Mamattah, R. S. (2016). Students' perceptions of E-learning. Linköping: Linköpings Universitet. 
Nelson, B. C., \& Erlandson, B. E. (2012). Design for learning in virtual worlds. New York: Routledge.

Ngampornchai, A., \& Adams, J. (2016). Students' acceptance and readiness for Elearning in Northeastern Thailand. International Journal of Educational Technology in Higher Education, 1-13.

Nwlink. (2010). Computer based training (CBT). Retrieved from Nwlink: http:/ / www.nwlink.com/ donclark/hrd/history/cbt.html

Pacansky-Brock, M. (2012). Best Practices for Teaching with Emerging Technologies. Routledge.

Putra, Y. M. (2020). Pahami social distancing, kenali cara kerja 'musuh'. Retrieved from Republika: https://republika.co.id/berita/q7g990284/pahami-social-distancingkenali-cara-kerja-musuh

Rahardyan, A. (2020, Juli 5). Pembelajaran online perlu evaluasi, jangan permanen dulu. Retrieved from

Bisnis.com: https://kabar24.bisnis.com/read/20200705/79/1261724/pembelajaran-onlineperlu-evaluasi-jangan-permanen-dulu

Reyes-Chua, E., Sibbaluca, B. G., Miranda, R. D., Palmario, G. B., Moreno, R. P., \& Solon, J. P. (2020). The status of the implementation of the e-learning classroom in selected higher education institutions in region iv-a amidst the Covid-19 crisis. Journal of Critical Reviews, 253-258.

Rizal, J. G. (2020). Benarkah virus corona penyebab Covid-19 berasal dari pasar Wuhan? Retrieved from

Kompas: https://www.kompas.com/tren/read/2020/04/09/061000865/benarkah-viruscorona-penyebab-covid-19-berasal-dari-pasar-wuhan

Ryan. (2020). Types of e-learning and at-home education options for kids and teens. Retrieved from iD Tech: https:/ / www.idtech.com/blog/types-of-elearning

School Education Gateway. (2020). Survey on online and distance learning - Results. Retrieved from School Education Gateway: https://www.schooleducationgateway.eu/en/pub/viewpoints/surveys/surveyon-online-teaching.htm

Siagian, K. (2020). Kesenjangan Konektivitas di Pembelajaran Jarak Jauh Indonesia. Retrieved from Dailysocial.id: https://dailysocial.id/post/kesenjangan-konektivitas-dipembelajaran-jarak-jauh-indonesia

Sugiyono. (2011). Metodologi penelitian pendidikan. Bandung: Alfabeta.

Sugiyono. (2016). Metode penelitian kuantitatif, kualitatif, dan kombinasi (Mixed Methods). Bandung: Penerbit Alfabeta.

Sun, A., \& Chen, X. (2016). Online education and its effective practice: A research review. Journal of Information Technology Education: Research, 15, 157-190.

Wijaya, C. (2020). PSBB Jakarta mulai 10 April selama dua minggu, namun pakar menyebut hasil efektif satu bulan untuk tekan Covid-19. Retrieved from BBC Indonesia: https://www.bbc.com/indonesia/indonesia-52194441

Worldometers. (2020). COVID-19 coronavirus pandemic. Retrieved from worldometers: https://www.worldometers.info/coronavirus/?utm_campaign=homeAdvegas1? /embed/fd0k_hbXWcQ 
The Rise of E-Learning in COVID-19 Pandemic in Private University: Challenges and Opportunities

* Daniel Hermawan, S.AB., M.Si., MBA. (Corresponding Author)

Department of Business Administration, Faculty of Social and Political Science, Parahyangan Catholic University,

Jl. Ciumbuleuit No. 94, Bandung, West Java, Indonesia 40141

Email: daniel.hermawan@unpar.ac.id 